\title{
THE DIGITAL ECONOMY AND THE QUEST FOR PRIVACY PROTECTION IN BANGLADESH: A COMPARATIVE LEGAL ANALYSIS
}

\author{
Mohsin Dhali* \\ Sonny Zulhuda** \\ Suzi Fadhilah***
}

\begin{abstract}
The present unbridled advancement in the field of information and communication technology has resulted in individuals being thrust at a crossroad, where refusing to sacrifice one's privacy would mean the denial of technological benefits. Concern for privacy begins once a child is born into this world where the right to privacy could now be argued needs to be considered as one of the basic human rights similar to other inalienable rights such as the right to life and liberties. Bangladesh is one of the countries that has not given explicit recognition to the right of privacy. This is evident from the absence of explicit indications of the right to privacy in the Constitution of Bangladesh and judicial interventions make the constitutional protection of privacy questionable. The purpose of the present study is to find out whether the right to privacy is in fact recognized and protected by the Constitution of Bangladesh by examining specific provisions in the Constitution of Bangladesh to locate provisions that could be relied on to show that a sliver of recognition could be given to the right of privacy in Bangladesh. This position is then compared to other jurisdictions, especially the common law jurisdictions. The study finds that although Article 43 of the Constitution guarantees limited protection that encompasses the right to privacy of home and correspondence but if read together with the right to life and liberty in Article 32, it could be argued that these are viable provisions in recognizing the right to privacy under the Constitution of Bangladesh.
\end{abstract}

* Ph.D. Candidate, Ahmad Ibrahim Kulliyyah of Laws, International Islamic University Malaysia. Email: mohsindhali17@gmail.com.

** Associate Professor, Ahmad Ibrahim Kulliyyah of Laws, International Islamic University Malaysia. Email: sonny@iium.edu.my.

*** Assistant Professor, Ahmad Ibrahim Kulliyyah of Laws, International Islamic University Malaysia. Email: suzi@iium.edu.my.

[Received: 13 April 2019, Accepted: 11 ecember 2019, Published: 28 December 2020] 
Keywords: right to privacy, protection of privacy, privacy under Bangladesh Constitution, information and communication technology in Bangladesh.

\title{
EKONOMI DIGITAL DAN PENCARIAN KAEDAH MEMELIHARA HAK PRIVASI DI BANGLADESH: SATU ANALISA PERBANDINGAN UNDANG-UNDANG
}

\begin{abstract}
ABSTRAK
Kemajuan yang melampau dalam bidang teknologi maklumat dan komunikasi telah menyebabkan setiap individu berada didalam keadaan serba salah. Jika mereka menolak teknologi tersebut atas nama perlindungang hak privasi, mereka akan kehilangan pelbagai manfaat yang dijanjikan oleh penggunaan teknologi tersebut. Kekhuatiran mengenai hak privasi bermula sebaik sahaja seorang anak dilahirkan ke dunia. Kini hak privasi patut di anggap sebagi hak asasi manusia yang sama pentingnya dengan hak-hak yang tidak dapat dilepaskan yang lain seperti hak kehidupan dan hak untuk hidup bebas. Bangladesh adalah salah satu negara yang tidak mengiktiraf hak privasi secara khusus. Hal ini ketara kerana perlembagaan Bangladesh tidak menyatakan hak privasi secara khusus. Selain itu, tiada keputusan mahkamah yang menyebut tentang pemuliharaan hak tersebut secara nyata. Ini telah menyebabkan hak privasi di anggap sebagai hak yang boleh di persoalkan. Kajian ini bertujuan untuk menjawab persoalan samada hak privasi diiktiraf dan dilindungi perlembagaan Bangladesh walaupun tiada peruntukan khas yang menyebutnya dengan memeriksa peruntukan tertentu yang boleh diguna pakai bagi menunjukkan bahawa sebenarnya hak privasi diiktiraf di Bangladesh. Kedudukan ini akan di bandingkan dengan kedudukan beberapa bidang kuasa, terutamanya dari negara yang mengamalkan undang-undang am atau common law. Kajian ini mendapati bahawa walaupun Artikel 43, Perlembagaan Bangladesh hanya memberikan jaminan yang terhad terhadap hak privasi, dimana ianya merangkumi hak privasi di rumah dan surat menyurat, namun jika dibaca bersama dengan hak untuk kehidupan and kebebasan seperti yang terkandung dalam Artikel 32, maka ini turut membolehkan pengiktirafan diberikan kepada hak privasi dibawah perlembagaan Bangladesh.
\end{abstract}


Kata kunci: hak privasi, pemeliharaan privasi, privasi dalam perlembagaan Bangladesh dan undang-undang berkaitan teknologi informasi dan maklumat di Bangladesh.

\section{INTRODUCTION}

This development of law was inevitable. The intense intellectual and emotional life and heightening of sensations which came with the advance of civilization, made it clear to men that only part of the pain, pleasure, and profit of life lay in physical things. Thoughts, emotions, and sensations demanded legal recognition, and the beautiful capacity for growth which characterizes the common law enabled the judges to afford the requisite protection, without the interposition of the legislature. ${ }^{1}$

The first seminal write up of Warren and Brandeis came to surface and attracted the attention of people on how technological invention has gradually eroded the privacy of individuals and how it will continue to do so in the coming age. The concern for privacy is not a new phenomenon, but the concern is accelerated due to unprecedented development in the technological sector. The concern of Warren and Brandeis about privacy due to technological inventions at that moment was the tip of an iceberg. One of the most significant downsides of such technological development is the violation of privacy.

Individuals are, to some extent, responsible for sacrificing their own privacy. People are now consciously or unconsciously relying on technology because of the comfort and convenience brought by such technology in their mundane daily tasks. For instance, people are now, for their own pleasure or any other reasons, like to share their activities, upload photos in social media sites, share personal data through body fitness devices, share financial or health information with various companies and health care services to avail

Samuel D. Warren and Louis D. Brandeis, "The Right to Privacy," Harvard Law Review 4, no. 5 (December 15, 1890): 195, https://doi.org/10.2307/1321160. 
goods and services. Nevertheless, such convenience always comes with costs. ${ }^{2}$ The way technology work nowadays and the complicated the nature of the internet, keeps people in the dark about how their personal data has been used or with whom they are sharing the information with.

In such a situation, countries around the world are revamping or adopting laws to protect the privacy and personal data of their citizens. What Warren and Brandeis said, "the development of law is inevitable". Therefore technological development constantly challenges lawmakers to pull the bridle in order to prevent misuse of such technologies.

Presently, Bangladesh neither has a comprehensive data protection law nor any explicit provision in the Constitution. The present article limited its avenue by only focusing on the constitutional protection of privacy because the Constitution of a country is the first and foremost avenue to uphold and protect the fundamental rights of the citizens. The article starts with the definition and nature of privacy as well as the implication of modern technologies in eroding privacy. The discussion continues with a detailed analysis of the constitutional right to privacy in Bangladesh in comparison with legal precedents of Malaysia, India and other related jurisdictions. Although Bangladesh, being a common law country is not bound to follow legal precedents of other jurisdictions, these legal precedents have persuasive value and are continuously referred to by courts while deciding a matter of similar concern. Legal precedents of other common jurisdictions would help Bangladesh to form the notion of the right to privacy under the Constitution in the absence of the specific provision in the Constitution and lack of judicial interventions.

The Constitution of Bangladesh recognizes the right to privacy, but that is limited to home and correspondence. Besides,

2 The incident of Cambridge Analytica had obtained personal information of nearly 87 million Facebook users without their consent and harvested and used that data for political purposes. Although incident took place in early 2014 and also reported by several newspapers in 2015 such as the Guardian, the news caught the attention of world and policy makers and created much hype and public outcry when a former employee of Cambridge Analytica vouched the truth of such breach. 
there is no comprehensive law yet to develop to deal with the issue of data protection and privacy. Although there are few provisions scattered in different legislations that actively and passively deal with the issue of privacy, such provisions seem to be ineffective compared to the legislations adopted by different jurisdictions. For instance, section 26 of the Digital Security Act 2018 criminalizes the use of personal identifiable information without permission while section 63 of the Information and Communication Technology Act 2006 protects the privacy of electronic documents. Further, section 7 of the Right to Information Act 2009 bars publishing information that may infringe personal privacy of individuals. Besides that, the Bangladesh Bank Order 1972 and its related regulations also ensures the privacy of its financial information. Various studies have been conducted to analyse existing legal instruments, including study relating to constitutional of Bangladesh but a lack of detailed analysis made such studies of little use. $^{3}$

\section{DEFINING PRIVACY}

No commentators or authors are able to come to a consensus when it comes to the term 'privacy' which lead to ambiguity. It is not possible to give an exhaustive meaning of privacy because the notion of privacy, its nature and extent is constantly evolving and takes new meanings and forms with social, political, economic, technological changes and development. Apart from law, the concept of privacy has been defined by other disciplines such as sociology, psychology, information studies and computer science etc. None of these disciplines have been able to formulate any uniform concept of

3 Zahidul Islam and Asma Jahan, "Right to Privacy: Is It a Fundamental Right in Bangladesh?," Journal of Asian and African Social Science and Humanities 1, no. 1 (2015): 7; Md Ershadul Karim, “Citizen's Right to Privacy: Reflection in the International Instruments and National Laws," SSRN Scholarly Paper (Rochester, NY: Social Science Research Network, April 9, 2005), https://papers.ssrn.com/abstract=2592414; Advocate Md. Shahabuddin Molla and Sumiya Nahar, "Need of Personal Data Protection Laws in Bangladesh: A Legal Appraisal," IOSR Journal Of Humanities And Social Science 20, no. 8 (2015): 10; Himaloya Saha and Saquib Rahman, "Personal Data Protection Laws Concerning Bangladesh," IOSR Journal Of Humanities And Social Science, II, 20, no. 8 (2015): 10. 
privacy. Each discipline defines the term from their own perspective, for example, in computer science, the notion of privacy is defined in terms of information integrity. Meanwhile, philosophically, the idea of privacy denotes a moral right (treating people fairly or what are the right things to do). Apart from academic disciplines, the notion of privacy would be defined differently in various jurisdictions.

Even Warren and Brandeis avoided giving any conclusive definition of privacy, they simply referred to the right "to be let alone". ${ }^{4}$ But defining the right to privacy as the right "to be let alone" is literally misleading as one author contended that "privacy is constantly being juxtaposed with competing goods and interests, balanced against disparate needs and demands". Therefore, the nature and scope of privacy revolves around the various context, for instance, technological advancements leads to a new concept of privacy to come to the fore in which an individual's personal data being misused in various ways which was not imaginable before.

In his book, Daniel J. Solove refers to the concept of privacy as being "a concept in disarray", if viewed from a socio-legal perspective. He continues to observe;

Currently, privacy is a sweeping concept, encompassing (among other things) freedom of thought, control over one's body, solitude in one's home, control over personal information, freedom from surveillance, protection of one reputation and protection from search and interrogations. ${ }^{6}$

On the other hand, Alan Westin observed that, "man likes to think that his desire for privacy is distinctively human" but research indicates that virtually all species either human or animals share a need for privacy, which they realize through seclusion, territoriality, or small-group intimacy. ${ }^{7}$ The same author further refers to privacy as

4 Warren and Brandeis, "The Right to Privacy," 195.

5 David E. Pozen, "Privacy-Privacy Tradeoffs," University of Chicago Law Review 83 (2016): 222.

6 Daniel J. Solove, Understanding Privacy (Cambridge, Mass: Harvard University Press, 2008), 1.

7 Judith Wagner DeCew, "Privacy and Its Importance with Advancing Technology," Ohio Northern University Law Review 42 (2016 2015): 472. 
"...a cross-species and cross-cultural value and the claims to individual privacy in some form are universal for virally all societies." $"$

The notion of privacy may vary on a contextual basis, and one of the commentators refer to the three areas of privacy, for instance, informational privacy which involves the right to control over one's own information; physical privacy refers to the right to be free from unreasonable search and seizures by the government or law enforcement agencies; lastly, decisional privacy which includes the rights to make decision on fundamental issues of one's life such as marriage, abortion, contraception, procreation, child-rearing and sexual intimacy and every individual should be allowed to make these decisions without interference from any section of the society. ${ }^{9}$

On the other hand, after extensive research, Solove referred to six different understanding of privacy such as the right to be left alone; limited access to the self; secrecy; control over personal information, personhood or the protection of individual personality, individuality and dignity; and lastly intimacy. ${ }^{10}$ As such, the term privacy includes a variety of concepts which cannot be defined in a single term. Privacy is an essential part of the freedom of democracy but inconsistency in conceptualizing privacy persists. Presently, technological development has continuously shaped the concept of privacy since the landmark essay, "The Right to Privacy"11 by Brandeis and Warren. Nonetheless, it is imperative to formulate a method to conceptualise the notion of privacy in order to guide policymakers and the judiciary in choosing comprehensive legal solutions and legal interpretations to a problem. It is submitted that privacy can be defined as limiting access of others into an individual's personal affairs, either physical privacy or informational privacy or decisional privacy.

The notion of privacy is the juxtaposition of different concepts that not only limited to personal information or data but also

8 DeCew, 473.

9 F. H. Cate and B. E. Cate, "The Supreme Court and Information Privacy," International Data Privacy Law 2, no. 4 (November 1, 2012): 255-67, https://doi.org/10.1093/idpl/ips024.

10 DeCew, "Privacy and Its Importance with Advancing Technology," 22.

11 Warren and Brandeis, "The Right to Privacy," 193-220. 
extend to physical space, identity or personality of an individual, among other things. Such a wider notion of privacy leave Warren and Brandeis with no option but an undefined notion of privacy. Prosser did not define privacy either, but described the law of privacy to consist of "four distinct kinds of invasion of four different interests of the plaintiff'. ${ }^{12}$ The arguments made by the Prosser in his work in order to identify and establish the existence of the common law tort of privacy. The four distinct torts laid down by Prosser are classic examples of the different aspects of privacy violations. These four torts are:

- Intrusion upon the individual's seclusion or solitude, or into his private affairs;

- Public disclosure of embarrassing private facts about an individual;

- Publicity that places an individual in a false light in the public eye;

- Appropriation of an individual's name or likeness for the advantage of another. ${ }^{13}$

Among these four invasions, 'intrusion upon seclusion or private affairs' and 'disclosure and misuse of private information' are the most important elements of the right to privacy. These two aspects of privacy protection are briefly discussed as follows:

\section{i. Intrusion Upon Seclusion or Private Affairs}

Intrusion of solitude occurs when someone intrudes upon personal affairs of another. Such intrusion can be physical or non-physical, for instance, eavesdropping, wiretapping, peeping, surveillance, photographing and video recording without consent among others. The intrusion must be intentional, unauthorized as well as offensive or objectionable to a reasonable person. ${ }^{14}$ In the opinion of Prosser, intrusion upon seclusion would be useful to fill the vacuums "left by

12 William Prosser, "Privacy," California Law Review 48, no. 3 (August 31, 1960): 389, https://doi.org/doi:10.15779/Z383J3C.

13 Prosser, "Privacy," 389.

14 Prosser, 389-92. 
trespass, nuisance, the intentional infliction of mental distress, and whatever remedies there may be for the invasion of constitutional rights". ${ }^{15}$

\section{ii. Disclosure or Misuse of Private Information}

Disclosure of private facts denotes unauthorized publication or disclosure of information relating to the private life of another. This is the most common and widely accepted type of privacy violation. The disclosure of the information would be considered offensive and objectionable to a reasonable person with ordinary sensibilities.

Intruding upon seclusion and disclosure of private information are the most common causes of action in privacy tort. As mentioned earlier, legal protection of privacy takes many forms, for instance, constitutional protection (explicitly or impliedly), common law protection, sectoral based protection and comprehensive protection (data protection law). The present study is limited its discussion on the constitutional protection.

\section{TECHNOLOGICAL DEVELOPMENT AND PRIVACY CONCERN IN BANGLADESH}

Bangladesh is gradually keeping up with the global technological arena of the rest of the world. The rampant cyber threat is now a common picture in Bangladesh. The hackers escaped with \$81 million from Bangladesh Bank, the central bank of Bangladesh is the glaring example of cybersecurity vulnerability in Bangladesh. ${ }^{16} \mathrm{~A}$ series of hacking incidents affecting different government websites, ${ }^{17}$

15 Prosser, 392.

16 Kim Zetter, “That Insane, \$81M Bangladesh Bank Heist? Here's What We Know," Wired, May 17, 2016, https://www.wired.com/2016/05/insane-81m-bangladesh-bank-heistheres-know/.

17 "Several Government Websites Hacked," The Daily Star, April 11, 2018, https://www.thedailystar.net/country/bangladesh-governmentwebsites-hacked-demanding-quota-system-reform-1561267. 
public universities, ${ }^{18}$ Facebook IDs of celebrities ${ }^{19}$ and politicians are posing a challenge to the cybersecurity system and regulatory framework of Bangladesh.

Apart from that, the threat to privacy exacerbated when it attacked the zone of personal affairs. Women are the most affected population in respect of cyberstalking, revenge pornography, hacking, surveillance, blackmailing, and cyberbullying. As assistant director of the Bangladesh Telecommunication Regulatory Commission (BTRC) told AFP, "We are receiving a growing number of complaints about abuse and harassment of using fake IDs, doctoring photos, filming photos, filming porno footage with mobile phones and posting them on websites and hacking of websites." 20 Such incidents sometimes compel victims to take her own life or attempted to take life or lead to self-inflicted injuries.

On the other hand, the lack of a regulatory framework on privacy and data protection and accountability on the side of government leaves the government's digital websites with unfettered surveillance and personal data gathering power. On the ground of national security, the law enforcement agencies and other government authorities may direct telecommunication companies to provide personal information of their consumers. Besides, an independent institution, namely Bangladesh Computer Security Incident Response Team (BDCSIRT) has been formed by the government in order to monitor social networking activities and other subversive online activities. Literally, there is no supervisory authority to monitor activities of these organisations responsible for surveillance, though

18 "SUST Website Back after Hack," The Daily Star, April 5, 2018, https://www.thedailystar.net/country/shahjalal-university-of-sciencetechnology-sust-website-hacked-sylhet-1558444.

19 "Kanak Chapa's Facebook ID 'Hacked,"' The Daily Star, December 4, 2018, https://www.thedailystar.net/bangladesh-national-election2018/news/kanak-chapas-facebook-id-hacked-1669291.

20 Partha Sarker et al., "Women's Rights, Gender and ICTs in Bangladesh" (Global Information Society Watch, 2013), 71, http://www.bytesforall.org. 
BTRC is the only organisation to supervise the activities of these organisations. ${ }^{21}$

Bangladesh government's vision of 'Digital Bangladesh'22 attempts to keep pace with the rest of the world and this has accelerated technological implementation in every aspect of life. The digitalisation of government activities is apparent and can be seen in different initiatives taken by the government, such as online application of passport ${ }^{23}$, electronic Tax Identification Number (eTIN) registration, ${ }^{24}$ electronic tax filing system, ${ }^{25}$ registration for examination $^{26}$ and publication of result ${ }^{27}$, government circular, ${ }^{28}$ electronic health record system, online police clearance, ${ }^{29}$ National Identification (NID) system, ${ }^{30}$ birth and death registration,,${ }^{31}$ among

21 Shahed Siddique and Faisal Mahmud, "Tougher Social Media Monitoring on Cards," Theindependent, August 11, 2018, http://www.theindependentbd.com/post/161812.

22 Access to Information (A2I) Programme, Office of Prime Minister, "Strategic Priorities of Digital Bangladesh," January 2011, accessed February 10, 2019, https://a2i.gov.bd/wp-content/uploads/2017/11/4Strategy_Digital_Bangladesh_2011.pdf.

23 "Online Application for Bangladesh Machine Readable Passport (BGDMRP)," Department of Immigration and Passports, accessed February 27, 2019, http://www.passport.gov.bd.

24 "NBR TIN Registration," e-TIN Registration, accessed February 27, 2019, https://www.incometax.gov.bd.

25 "National Board of Revenue, Bangladesh," Taxpayer Online Service, accessed February 27, 2019, https://www.etaxnbr.gov.bd/tpos/home.

26 "Education Board Bangladesh - Registration," Ministry of Education, Education Board Computer Center, accessed February 27, 2019, http://www.educationboard.gov.bd/computer/search_registration.php.

27 "Education Board Bangladesh," Intermediate and Secondary Education Boards Bangladesh, accessed February 27, 2019, http://www.educationboardresults.gov.bd/.

28 "Gazettes Archive - Bangladesh Government Press," accessed February 27 , 2019 , https://www.dpp.gov.bd/bgpress/index.php/document/gazettes/140.

29 "Police Clearance," Police Clearance Certificate, accessed February 27, 2019, http://pcc.police.gov.bd.

30 "Election Commission Bangladesh," National Identity Registration Wing, accessed February 27, 2019, http://www.nidw.gov.bd/. 
others. In addition, providing biometrics is a mandatory requirement to buy a mobile sim card allowing telecommunication companies to use consumers' personal data as they seem fit in the absence of a proper regulatory framework. Even in some cases, there is a real chance to move such sensitive personal information outside the national border by foreign telecommunication service operating in Bangladesh.

In furtherance of achieving the vision of Digital Bangladesh, the government has already set up the national data centre. ${ }^{32}$ In order to ensure integrated governmental services and critical information exchange among government agencies, the government has started developing National Population Register (NPR) that will contain all basic information (name, address, parents' name, photograph including biometric data) about the citizenry.

\section{CONSTITUTIONAL PROTECTION OF PRIVACY IN BANGLADESH}

Bangladesh is a sovereign democratic republic. The Constitution of Bangladesh, being the embodiment of the will of the Sovereign People of the Republic of Bangladesh, is the supreme law in the country. The Constitution was adopted and enacted on 4th November of 1972 and came into effect on 16th December of 1972. Three branches, namely the Legislature, the Executive and the Judiciary; the Legislature make the law while the Executive runs the government, and the Judiciary ensures the enforcement of the provision of the Constitution. These three organs being established by the Constitution are therefore bound by its provisions. All actions and proceedings of these organs must conform with the Constitution and if made in violation of the Constitution, may be considered null and void.

Part III (Article 26-44) of the Constitution of Bangladesh guarantees the fundamental rights of the people of Bangladesh. The fundamental rights enumerated in Part III of the Constitution are also

31 "Office of the Registrar General, Registration of Births and Deaths, Department of Local Government," accessed February 27, 2019, http://br.lgd.gov.bd/.

32 "Datacenter Bangladesh," accessed February 27, 2019, http://www.datacenter.com.bd/. 
an illustration of human rights of the citizenry. Therefore, it is pertinent to say that the fundamental rights depicted in the Constitution are also fundamental human rights to the extent that is in accord with human rights. The Constitution protects these fundamental rights under Article 44. Article 44 empowers an individual to enforce such fundamental human rights under clause (1) of Article 102 of the Constitution. ${ }^{33}$ The preamble of the Constitution also reiterates the protection and upholding of fundamental human rights. The preamble of the Constitution says '...it shall be a fundamental aim of the State to realize through the democratic process ... fundamental human right and freedom, equality and justice, political, economic, and social, will be secured for all citizens'.

Furthermore, one of the essential aspects of Part III of the Constitution is that the rights enumerated in this part cannot be curtailed or abridged by ordinary legislation. Article 26 of the Constitution stipulates that all existing laws that are inconsistent with fundamental rights provision shall to the extent of such inconsistency become void on the commencement of the Constitution, and the State shall not make any law inconsistent with these rights. In the case of Jibendra Kishore v East Pakistan, the Supreme Court contended that the notion of the fundamental rights as being guaranteed by the Constitution cannot be taken away by the law, and it is not only inartistic but a fraud on the citizenry for the makers of the Constitution to say that a right is fundamental but it may be taken away by the law. ${ }^{34}$

Nonetheless, the fundamental rights enunciated in the Constitution are not absolute. Among 18 rights enumerated from Article 27 to 44,8 rights $^{35}$ are considered as absolute rights (that

33 Article 102 (1) of the Constitution of Bangladesh empower the High Court Division of the Supreme Court of Bangladesh to direct or order any person or authority involving in connection with the affairs of the Republic for the enforcement of the fundamental rights on the application of any aggrieved person.

34 Jibendra Kishore v East Pakistan, [1957] 9 DLR (SC) 21.

35 Equality before law (Article 27); Discrimination on grounds of religion etc. (Article 28); Equal opportunity in public employment (Article 29); Prohibition of foreign titles etc (Article.30); Safeguards as to arrest and detention (Article 33); Prohibition of forced labour (Article 34); 
cannot be changed by parliament except as provided in the Constitution) and other 6 rights $^{36}$ are subjected to reasonable restrictions imposed by the law. In addition, the grounds for imposing restrictions on fundamental rights are also enunciated in the Constitution, for instance, in the public interest (Article 36); in the interest of public order or public health (Article 37 and 43); in the interest of public order or morality (Article 38 and 41); in the interest of the security of the State, friendly relation with foreign State, public order, decency, or morality or in relation to contempt of court, defamation or incitement to an offence (Article 39). The test of measuring reasonableness lies with the Supreme Court of Bangladesh. If the court considers the restriction imposed to be unreasonable it can declare such restriction illegal and void. The court has the authority to employ an intensive level of scrutiny to assess the lawfulness of the exercise of public powers when fundamental rights are at stake. ${ }^{37}$

Unlike India, the Constitution of Bangladesh recognises the right to privacy in a narrower sense through Article 43, regarding the prohibition on unreasonable search and seizures and privacy of correspondence and other means of communication under the heading of right to property that is similar to the Fourth Amendment of the Constitution of the United States. Besides, the Constitution also does provides the right to life and personal liberty under Article 32 which is similar to Fourteenth Amendment of Constitution of United States, Article 21 of the Indian and Article 5 of Malaysian Constitution. Like India, Malaysia, the United States of America and the United Kingdom, the legal system of Bangladesh is largely based on common law principles. So far, there is yet any legal precedent regarding the Constitutional right to privacy in Bangladesh. In order to determine the extent and application of Article 31, 32 and 43 in accommodating the 'zone of privacy' within the Constitution, it is arguably pertinent to go through precedents in other jurisdictions

Protection in respect of trial and punishment (Article 35); Enforcement of Fundamental Rights (Article 44).

36 Freedom of movement (Article 36); Freedom of Assembly (Article 37); Freedom of Association (Article 38); Freedom of thought and conscience and of speech (Article 39); Freedom of religion (Article 40); Protection of home and correspondence (Article 43).

37 Mahmudul Islam, Constitutional Law of Bangladesh, 2nd ed. (Dhaka: Mullick Brothers, 2002), 92. 
apart from analyzing present provisions of the Constitution. The prime reason for analysing precedents of other common law jurisdictions is due to the persuasive value of these precedents in the legal system of Bangladesh, though the court is not obliged to follow precedents of other common law jurisdictions.

Article 31 of the Constitution states;

To enjoy the protection of law, and to be treated in accordance with law, . . is the inalienable right of every citizen . . . in particular no action detrimental to the life, liberty, body, reputation or property of any person shall be taken except in accordance with law.

Meanwhile, Article 32 says, "No person shall be deprived of life or personal liberty save in accordance with law."

Articles 31 and 32 are connected to one another, as the former ensures equal protection of law as an inalienable rights of every citizen and the latter provides protection against deprivation of life and liberty save in accordance with the law. Right to life and liberty is an integral part of fundamental rights. The existence of other basic and fundamental rights depends on the proper enjoyment of the right to life and personal liberty. The importance of the right to life and personal liberty is apparent from the significant protection given by Article 32 than Article 31. Although Article 31 provides protection to life and personal liberty, Article 32 provided extra protection against deprivation of life and personal liberty. The reason behind emphasising on the importance of the right to life and personal liberty is that the right to privacy is implicit under above mentioned right.The right to life is not limited to the right to livelihood and liberty of personal movement. The right is more than that. It refers to:

The right of an individual to be free in the enjoyment of all his faculties; to be free to use them in all lawful ways; to live and work where he will; to earn his livelihood by any lawful calling; and to pursue any livelihood or avocation and for the purposes to enter into all contracts which seem to be necessary, proper or essential to carry out successful fulfilment of these purposes. ${ }^{38}$

38 Islam, 190. 
As mentioned earlier, privacy has many facets. The right to privacy is intrinsically related to the right to life, liberty, property and human dignity. Intrinsically, this denotes privacy inherently attaches to the human being, for instance, the right to live one's life the way he sees fit or right, to exercise one's intellectual facilities or the right to be alone. These rights accrued to the people are not only by law, but these rights are innately related to human nature. So, generally, the right to privacy denotes the right of the individual to do or omit to do anything unless or until it goes against the law. Privacy also refers right to have control over one's personality. Right to life and personal liberty is the natural and inalienable right of an individual and accrues before someone even comes into life. Similar to that, the right to privacy is a natural and inalienable right. It is vested on the individual by natural law. In the opinion of Rossiter, natural law refers to individual's right to live his life as he deems fit, his right to quite an existence as well as his right to anonymity. ${ }^{39}$

In the case of Pavesich $v$ New England Life Ins. Co, Cobb J. held that "the right to privacy has its foundations in the instincts of nature. A right to privacy in matters purely private is therefore derived from natural law." ${ }^{40}$ Cobb J. further opined that all natural rights are absolute, immutable, and belong to every human being whether in the State of nature or in society. ${ }^{41}$ Further, in the Pavesich case Justice Cobb also held that the right to privacy is a part of "liberty", ${ }^{42}$ guaranteed by the due process of law. ${ }^{43}$

39 "Privacy after Griswold: Constitutional or Natural Law Right," Northwestern University Law Review 60, no. 6 (1966-1965): 813-833.

40 Pavesich v New England Life Ins.Co, 122 Ga. 190 ; 50 S.E. 68 ; 1905 Ga. LEXIS 156.

41 Pavesich v New England Life Ins.Co, 122 Ga. 190 ; 50 S.E. 68 ; 1905 Ga. LEXIS 156.

42 The Fourteenth Amendment of the Constitution of USA guarantees 'the right to liberty'.

43 Pavesich v New England Life Ins.Co, 122 Ga. 190 ; 50 S.E. 68 ; 1905 Ga. LEXIS 156. Justice Cobb opined that "Liberty includes the right to live as one will, so long as that will does not interfere with the rights of another or of the public. One may desire to live life of seclusion; another may desire to live a life of publicity. . . Each may entitled to a liberty of 
The forgoing judicial notes and analysis indicate that these rights are not given by any states, and no individual shall be capable of alienating such rights to others. The individual have these rights from their birth as a human being irrespective of their races, genders, qualifications and colours. In the case of Kesavananda Bharati $v$ State of Kerala, Justice Mathew opined that,

The social nature of man, the generic traits of his physical and mental constitution, his sentiments of justice and the morals within, his instinct for individual and collective preservations, his desire for happiness, his sense of human dignity, his consciousness of man's station and purpose in life, all these are not products of fancy but objective factors in the realm of existence... ${ }^{44}$

Enjoyment of right to privacy is subjected to respect and uninterrupted exercising of rights of other individuals, for instance, inter alia, right to respect the privacy of others. The rights are limited for the purpose of the public interest, prevention of crimes, disorder, protection of health, morals, protection of rights and freedom of others. ${ }^{45}$

Article 43 of the Constitution affords protection of certain aspects of the privacy interest. Article 43 imposes restriction on illegal entry, search and seizure and privacy of correspondence and other means of communication. This provision is a safeguard against illegal search, seizure and surveillance. The provision not only deals with physical search and seizure but also equally applicable in respect of search without physical involvement for example wiretapping, surveillance camera etc. The Supreme Court of the United States decided that using a thermal imaging system without a warrant is considered as illegal search and as such unlawful. ${ }^{46}$ It can be said that the term search and seizure are not limited to tangible objects, it also

choice as to his manner of life, and neither an individual nor the public has right to arbitrary take away from him this liberty."

44 Kesavananda Bharati Sripadagalvaru and Ors v State of Kerala, [1973] 4 SCC 225.

45 Mr. X v Hospital Z, [2003] 1 SCC 500; Whalen v. Roe, 429 U.S. 589; 97 S. Ct. 869; 51 L. Ed. 2d 64; 1977 U.S. Lexis 42.

46 Danny Lee Kyllo v United States, 533 U.S. 27; 121 S. Ct. 2038; 150 L. Ed. 2d 94; 2001 U.S. LEXIS 4487. 
extend to intangible objects. Although the provision does not specifically mentioned anything about technology or technological technique of search and seizure, proper interpretation could accommodate non-physical means of search and seizure. In the case of Gompers v United States, Justice Holmes opined that,

The provisions of the Constitution are not mathematical formulas having their essence in their form; they are organic living institutions transplanted from English soil. Their significance is vital not formal; it is to be gathered not simply by taking the words and a dictionary, considering their origin and the line of their growth. ${ }^{47}$

The Constitution is not completely devoid of any protection against violation of privacy. Limited or specific protection, for example, physical and communicational privacy is afforded by Article 43 of the Constitution. As discussed earlier, privacy encompasses various aspects of life and elements of human life may arise in heterogenous contexts from the other facets of freedom and dignity recognised and guaranteed by the fundamental rights. Apart from the physical and communicational aspects, the concept of privacy also does, among other things, include preservation of intimacies, the sanctity of family life, marriage, procreation, human dignity and reputation. Thus, privacy subsumes a number of entitlements and interests, but Article 43 of the Constitution postulates specifically home, correspondence and communication. Therefore, Article 43 of the Constitution is not capable of protecting all areas of privacy interests.

Baed on the interpretation given by modern scholars, in order to accommodate all related interests of privacy under the penumbra of constitutional protection, Article 32 of the Constitution would be considered as a proper provision. It is submitted that the scope of Article 32 is more extensive than Article 43 of the Constitution. The crux of the right to life and liberty as guaranteed under Article 32 is not limited to livelihood or not being unlawfully detained only. The provision is capable of housing plurality and diversity of culture and protecting heterogeneity of interests. It is submitted that Article 32 of

47 Gompers v United States, 233 U.S. 604; 34 S. Ct. 693; 58 L. Ed. 1115; 1914 U.S. LEXIS 1205. 
the Constitution is flexible enough to recognise the right to privacy under the Constitution of Bangladesh.

Scholars, judges and authors of different jurisdictions have taken different stances trying to establish the right to privacy under the Constitution by employing various interpretive methods. However, all these interpretations and judicial decisions have their deficiencies in establishing an absolute right to privacy in the absence of a specific provision in the Constitution. In order to establish the constitutional right to privacy, consistent judicial intervention is imperative. The Constitution is a dynamic instrument; it should have the flexibility to adapt to changing circumstances. The liberal and prismatic interpretive approach of right to life and liberty of Article 32 of the Constitution would seem appropriate in recognising a constitutional right to privacy in Bangladesh.

A recent decision ${ }^{48}$ of the Supreme Court of India which recognised the right to privacy as a fundamental right under the auspices of the right to life and liberty as enshrined in Article 21 of the Indian Constitution would be a guiding principle for Bangladesh's future judicial intervention in recognising the constitutional right to privacy. Although the judiciary of Bangladesh is not bound to follow Indian precedents or any other foreign precedent, it is evident from the long judicial practices ${ }^{49}$ that the court often refers to foreign precedents, for example, Indian precedents to resolve an issue. The Supreme Court of Bangladesh can play a vital role in this regard. B H Chowdhury J. in Anowar Hossain v Bangladesh stated that:

\begin{abstract}
What is necessary is to have judges who are prepared to fashion new tools, forge new methods, innovate new strategies and evolve a new jurisprudence, who are judicial statesman with social vision and creative faculty and who have, above all, a deep sense of commitment to the constitution with the activist approach and obligation for accountability, not to in power nor to the opposition... ${ }^{50}$
\end{abstract}

\footnotetext{
48 Justice K S Puttaswamy (Retd.) and Anr v Union of India and Ors, [2017] 10 SCC 1.

49 Khondhker Delwar Hossain v Bangladesh Italian Marble Works Ltd and Others, [2010] 62 DLR (AD) 298; Anwar Hossain Chowdhury v. Bangladesh, [1989] BLD (AD) (Special) 1.

50 Anwar Hossain Chowdhury v Bangladesh, [1989] BLD (AD) (Special) 1 .
} 
A thorough reading of the judgment indicates two methods for future judicial development, for instance, either develop an entirely new jurisprudence or devise new jurisprudence based on other sources or jurisdictions. In respect of recognising the existence of the right to privacy under the Constitution, the court can take into consideration of the recent Indian decision because Article 32 of Bangladesh Constitution and Article 21 of the Indian Constitution are in pari materia besides Indian precedents having persuasive value in the Bangladesh legal system.

\section{BANGLADESH'S OBLIGATION UNDER INTERNATIONAL LAW}

The respect for privacy as a fundamental human right is an integral part of Bangladesh's promise to the international human rights regime. Article 25 of the Constitution of Bangladesh is a reflection of such promise. This provision imposes an obligation on the State to respect principles of international law including principles enumerated in the United Nations (UN) Charter. Bangladesh is a party to both the Universal Declaration of Human Rights (UDHR) and the International Covenant on Civil and Political Rights (ICCPR). Both the instruments recognise the right to privacy as fundamental human rights. Article 12 of the UDHR protects against arbitrary interference of an individual's privacy, family, home and correspondence. Furthermore, Article 17 of the ICCPR has provided similar provision and requires member states to adopt legislation and other measures to ensure the privacy of citizens.

Although Article 25 of the Constitution requires the State to respect international principle, the state or judiciary is not legally bound to enforce such a principle in cases of violation as such principles cannot be enforced unless they become part of domestic legislation. On the other hand, Article 8 (2) of the Constitution states that the principles mentioned in Article 25 shall be used for making law, shall be a guide to the interpretation of the Constitution and other laws of Bangladesh, shall form the basis of the work of the state and its citizens, but shall not be judicially enforceable in the event of any violation. The notion contained in Article 25 is also reflected in several case decisions for example in the case of Bangladesh National 
Women Lawyers (BNWLA) v Government of Bangladesh and others, the court was of the opinion that,

Our court will not enforce those Covenants as treaties and convention, even if ratified by the State, are part of the corpus juris of the State unless those are incorporated in the municipal law. However, the court can look into these conventions and covenants as an aid to interpretation of the provision of Part III, particularly to determine the rights implicit in the right to life and the right to liberty but enumerated in the Constitution. ${ }^{51}$

To give the full effect of such principles, they should be incorporated into domestic law passed by due process, for instance, India enacted the Protection of Human Rights Act, 1993 by incorporating principles of international law referring to the ICCPR as human rights instrument. The rights enunciated in UDHR are clearly reflected in Part II and Part III of the Constitution. Nevertheless, the problem is that the international law principles are not incorporated in any national law. In BNWLA v Government of Bangladesh and others, Sheikh Hassan Arif, J opined,

It has now been settled by several decisions of this subcontinent that when there is gap in the municipal law in addressing any issue, the court may take recourse international conventions and protocols on that issue . . . until the national legislature enacts laws in this regard. ${ }^{52}$

In this regard, Justice Arif also quoted the observation of $\mathrm{Mr}$ Justice B. B. Roy Chowdhury in the case of Hussain Mohammad Ershad v Bangladesh \& others, 21 BLD (AD) 2001 as held that the national court should not ignore the international obligations outright; if the domestic laws are not clear the court should take recourse of principles incorporated in international instruments, but if domestic laws are clear and inconsistent with international obligation then the

51 Bangladesh National Women Lawyer Association (BNWLA) $\mathrm{v}$ Government of Bangladesh and others, [2011] 31 BLD (HCD) 324.

52 [2011] 31 BLD (HCD) 332 at para 9. 
court should follow domestic law and shall report such inconsistencies to the lawmakers. ${ }^{53}$

Furthermore, if the domestic laws are not clear enough or there is nothing in the domestic law, the national court can take recourse of the principles incorporated in the international instruments. ${ }^{54}$ So, it is apparent that the court always takes the restrictive approach in applying international principles unless they are incorporated into domestic law. However, the court leaves the option open to take recourse of the international convention and protocol in the context of any gap in municipal law.

Most of the reported cases in respect of the enforceability of international principles were decided in the context of sexual harassment of girls and women in education and workplace, eveteasing and stalking in the streets, public and privacy places, public and private transports and rights of the children among other things. No case is yet to be decided in respect of the right to privacy. In such a situation, it does not mean that there is no judicial enforceability of international principles as people is allowed to enforce such principle before the court, although it will depend on the response of the judiciary to enforce it. It should be noted that the Supreme Court of Bangladesh are empowered under Article $111^{55}$ of the Constitution to issue guidelines and directives, and such directives have a binding effect on all concerned authorities and people. They are to be implemented within the country until an effective legal measure is taken or any legislation is enacted relating to the matter of concern.

[2011] 31 BLD (HCD) 332 at para 9.

54 State v Metropolitan Police Commissioner, [2008] 60 DLR 660.

55 Article 111 of the Constitution says, "The law declared by the Appellate Division shall be binding on the High Court Division and the declared by either division of the Supreme Court shall be binding on all courts subordinate to it." 


\section{PROTECTION OF PRIVACY IN OTHER JURISDICTIONS}

\section{Right to Privacy in the Malaysian Constitution ${ }^{56}$}

There is no express provision of the right to privacy in the Constitution of Malaysia. Judicial interventions of the Malaysian courts indicate that the right to privacy can be accommodated under the auspices of fundamental rights enshrined in Part II of the Federal Constitution. The closest connection concerning the right to privacy can be deduced from Article 5 (1) of the Constitution that states, "No person shall be deprived of his life or personal liberty save in accordance with law". The provision is similar to Article 21 and Article 32 of the Indian Constitution and Constitution of Bangladesh, respectively.

The right to privacy is a subset of fundamental right and implicit in the right to life and liberty. It was first reflected in the case of Sivarasa Rasiah v Badan Peguam Malaysia \& Anor that while interpreting Article 5 (1) of the Constitution, the Federal Court of Malaysia opined that, "It is patently clear from a review of the authorities that "person liberty" in art. 5(1) includes within its compass other rights such as the right to privacy." 57

At present, although the right to privacy is not expressly recognised as a fundamental right in the Constitution, it can be ascertained that such right is guaranteed under Article 5(1) of the Constitution. However, the judgment in Sivarasa case that recognised right to privacy under Article 5 (1) did not have a binding effect. In the opinion of Munir el at., the Malaysian courts would follow the approach of Sivarasa case in recognising the right to privacy under the federal Constitution. ${ }^{58}$

The decision is followed in the case of Toh See Wei v Teddric Jon Mohr \& Anor, ${ }^{59}$ the High Court of Penang came across to decide

56 Personal Data Protection Act (PDPA) 2010 of Malaysia deals with the personal data privacy issue in commercial sectors. The PDPA is not applicable to data processed by the government and only deal with data processed in commercial transaction.

57 [2010] 2 MLJ 333.

58 Abu Bakar Munir and Siti Hajar Mohd. Yasin, Personal Data Protection in Malaysia: Law and Practice (Malaysia: Sweet \& Maxwell Asia, 2010), 15.

$59 \quad$ [2017] MLJU 704. 
whether the right to privacy is recognised under Article 5 (1) of the Federal Constitution. The court did recognise the existence of the right to privacy as a constitutional right by giving reference to the Sivarasa case. The court also commented that "the right to privacy is a constitutional right must be treated cautiously." 60 Nevertheless, at present, the constitutional right to privacy was not applied due to the case being between two private individuals. Constitutional law, being a branch of public law, may not be enforced by an individual against another individual. The protection of Constitutional law only extends to the violation of an individual's legal right by the legislative or the executive or its related agencies. ${ }^{61}$

Judicial activism of Malaysian courts also postulates that the right to privacy is a subset of right to property thereby protected by Article 13 of the Federal Constitution. Justice Callow in the case of $P P v$ Lee Sin Long equated the right to privacy with the fundamental right to property. ${ }^{62}$ Further, Justice Bujang in the case of Chong Ching Jen v Mohd Irwan Hafiz Bin Md Radzi \& Ano ${ }^{63}$ affirmed the similar contention as "a person's privacy and the right to property are very basic rights of a man" and thereby protected under Article 13 (1) of the Federal Constitution. Zulhuda opined that it is not feasible to argue that the right to privacy is inexistence in the Federal Constitution based on the wide scope of the privacy that extends from the preservation of person's life to the protection of property. ${ }^{64}$

In a recent case, High Court of Johor Bahru in the case of Lew Cher Phow @ Lew Cha Paw \& Ors v Pua Yong Yong \& Anor ${ }^{65}$ held that the defendant had violated the right to privacy of the plaintiff by carrying out overt video surveillance on his neighbour's property, though the court did not mention any specific provision of

\footnotetext{
60 Toh See Wei v Teddric Jon Mohr \& Anor, [2017] MLJU 704 at para 56.

61 Beartice a/p AT Fernandez v Sistem Penerbangan Malaysia \& Ors, [2005] 3 MLJ 681.

62 PP v Lee Sin Long, [1949] 1 MLJ 51.

63 [2009] MLJU 159.
}

64 Sonny Zulhuda, "Right to Privacy: Development, Cases and Commentaries," in Constitutional Law and Human Rights in Malaysia: Topical Issues and Perspectives (Selangor, Malaysia: Sweet \& Maxwell Asia, 2013), 457.

65 [2011] MLJU 1195. 
the Federal Constitution in reference to its decision. The court further said

There is no specific provision in the Federal Constitution guaranteeing the right to privacy.... The fact that the right to privacy has not been specifically provided for does not preclude the court of law from holding that such a right exists... privacy is difficult to define with precision. It means different things to different people ... In the present case, the privacy in question relates to a person's right to respect for his private and family life and his home. ${ }^{66}$

The above decisions are a clear example that proper interpretive methods can accommodate the right to privacy as a fundamental human right under the Federal Constitution of Malaysia. In Sivarasa, while resolving the issue under Article 5(1), the Court should not limit itself to traditional and narrower interpretation; the right to life and liberty should be understood in their broadest sense. ${ }^{67}$

Earlier in the case of Pihak Berkuasa Sabah $v$ Sugumar Balakrishnan $^{68}$ the court rejected the idea of a generous interpretation of Article 5 (1), but this decision was further criticised in the Sivarasa case as being without merit. Furthermore, Dr Faruqi, in his write up, criticised the judicial approach of the court in interpreting human rights provisions enshrined in the Constitution of Malaysia as not being pragmatic enough. ${ }^{69}$

The nature of the Constitution is fundamentally different from any other statute passed by the parliament, and the approaches apply to interpret ordinary legislation should not be used in constitutional interpretation rigidly. ${ }^{70}$ In the case of Dato Menteri

66 Lew Cher Phow @ Lew Cha Paw \& Ors v Pua Yong Yong \& Anor, [2011] MLJU 1195.

67 Sivarasa Rasiah v Badan Peguam Malaysia \& Anor, [2010] 2 MLJ 333.

68 [2002] MLJ 72.

69 Prof. Dr. Shad Saleem Faruqi, "Constitutional Interpretation in a Globalised World," The Malaysian Bar, November 17, 2005, http://www.malaysianbar.org.my/constitutional_law/constitutional_inter pretation_in_a_globalised_world.html.

70 Faruqi. 
Othman bin Baginda \& Ano v Dato Ombi Syed Alwi bin Syed Idrus, the court stated

In interpreting a constitution two point must be borne in mind. First, judicial precedent pays a lesser part than is normal matters of ordinary statutory interpretation. Secondly, a constitution, being living piece of legislation, its provision must be construed broadly and not in pedantic way..." with less rigidity and more generous than other Acts. $^{71}$

Judicial notes from the courts showed that the notion of right to privacy is an implied right under the right to life and liberty as well as right to property. ${ }^{72}$ But in the opinion of the present authors, recognising the right to privacy as a fundamental human right under the right to life and liberty would seem to be a feasible option because the scope of the right to life and liberty is wider than the right to property. The word 'life' under Article 5 (1) is no longer limited to the meaning of mere animal existence but does include other aspects of life such as livelihood and the meaning 'personal liberty' has no longer only refer to not being unlawfully detained..$^{73}$ In the case of Lee Kwan Woh v Public Prosecutor, Gopal Sri Ram FCJ opined that,

On no account should a literal construction be placed on its language, particularly upon those provisions that guarantee to individuals the protection of fundamental rights.. . . Indeed, the prismatic interpretation of the Constitution give life to abstract concepts such as 'life' and 'personal liberty' in art $5(1) .^{74}$

\section{Privacy Protection in India}

In India, the constitutional right to privacy has been developed through many judicial interventions over the past sixty years. The courts were giving contradictory opinions, sometimes remaining

71 Dato Menteri Othman bin Baginda \& Ano v Dato Ombi Syed Alwi bin Syed Idrus, [1980] 1 MLJ 29.

72 Zulhuda, "Right to Privacy: Development, Cases and Commentaries," 465.

73 Faruqi, "Constitutional Interpretation in a Globalised World."

74 Lee Kwan Who v Public Prosecutor, [2009] 5 MLJ 301. 
silent in deciding constitutional right to privacy. All these uncertainties arise due to the absence of a specific provision in the Constitution. Previously, reliance was made on two decided cases such as M P Sharma and Karak Singh until recently the Supreme Court of India through its landmark judgement in Justice $K S$ Puttaswamy (Retd.) v Union of India, a nine-judge bench of Supreme Court of India unanimously ruled that privacy is a constitutionally protected right in India under Article $21 .{ }^{75}$ Dr D Y Chandrachud (CJ) opined that,

Privacy is a constitutionally protected right which emerges primarily from the guarantee of life and person liberty in Article 21 of the Constitution. Elements of privacy also arise in varying contexts from the other facets of freedom and dignity recognized and guaranteed by the fundamental rights contained in Part III. ${ }^{76}$

In this case, the validity of the government Aadhaar project by Justice K.S. Puttaswany (retired) in 2012 was challenged. The Aadhaar project aims to build an electronic database of personal identity whereby every Indian citizen will be issued with a 12-digit number, which is associated with their biometric data such as iris scan and fingerprints. The petitioner challenged the constitutionality of such a programme on the ground that it is a clear violation of the right to privacy. Initially, the matter was before a three-judge bench court; Subsequently, the matter was referred to a five-judge Constitutional bench which ordered a nine-judge Constitutional Bench to hear the matter.

Previously in M P Sharma v Satish Chandra ${ }^{77}$ and Kharak Singh v. Uttar Pradesh ${ }^{78}$ the decisions that the Indian Constitution does not protect the right to privacy were overruled by the judgement in the case of Puttaswany v. Union of India which states that 'privacy is not a right guaranteed by the Indian Constitution is not reflective of the correct position'. ${ }^{79}$

\footnotetext{
75 [2017] 10 SCC 1.

76 [2017] $10 \mathrm{SCC} 1$ at part T para 3(C).

$77 \quad 1954$ SCR 1077.

781964 SCR (1) 332.

79 [2017] 10 SCC 1 at para 3.
} 
As mentioned earlier, recognition of the constitutional right to privacy in India has developed as a result of a series of judicial interventions through the passage of time. The Supreme Court of India, from time to time, came across the challenges of deciding whether the Constitution of India recognises the right to privacy. Over the years, the Court had to decide on the issue of surveillance, ${ }^{80}$ search and seizure, ${ }^{81}$ wiretapping, ${ }^{82}$ homosexuality, ${ }^{83}$ informational privacy, ${ }^{84}$ among other things. In the absence of a specific provision in the Constitution, the court while deciding the issue of privacy expands the personal liberty clause to include the right to privacy through broad interpretation. Eventually, the Supreme Court of India had formally recognised the right to privacy as constitutionally protected fundamental human rights under the auspices of right to life and personal liberty.

In regards to the information privacy under the Constitution, in Thalappalam Service Cooperative Bank Limited $v$ State of $\operatorname{Kerala}^{85}$, the court rejected the notion of information privacy protection under the Constitution. Even in the case of Puttaswamy $v$ Union of India, the Court did not specifically recognise the right to information privacy under the Constitution but talked about the importance of information privacy in the modern technological era and recommended the government to set up a robust regime for data protection which, in the opinion of the court, requires a careful and sensitive balance between individual interest and legitimate concerns of the State. ${ }^{86}$ As per the recommendation, India has already drafted 'Personal Data Protection Bill' that awaits to be passed by the parliament.

80 Gobind v State of Madhya Pradesh, [1975] 2 SCC 148; Malak Singh v State of Punjab \& Haryana, [1980] 2 SCR 311.

81 District Registrar \& Collector, Hyderabad v Canara Bank, [2004] 1 SCC 496.

82 People's Union for Civil Liberties v Union of India, [1996] 1 SCC 301.

83 Naz Foundation v Government of NCT of Delhi, [2009] 160 Delhi Law Times 277.

84 District Registrar \& Collector, Hyderabad v Canara Bank, [2005] 1 SCC 496; Thalappalam Service Cooperative Bank Limited v State of Kerala, [2013] 16 SCC 82.

85 [2013]16 SCC 82.

86 [2017] 10 SCC 1 at paras 62-76. 


\section{FUTURE DIRECTION AND CONCLUSION}

The ultimate protection one could afford is through the Constitution, though recognition of the constitutional right to privacy is not the panacea for all privacy-related problems considering the present technological development. Bangladesh should consider the following solution:

1. The Judiciary of Bangladesh needs to be agile and open to reform, among others by adopting the constitutional interpretation to the right to life and liberty in India and elsewhere.

a. The right to privacy in the digital age grows more complex therefore there is a need to improve the whole legal and regulatory framework in Bangladesh including that govern various sectors such as Information and Communication technology (ICT). This can be done through parliamentary action i.e. by adopting new law relating to the data privacy with enforceability both in the private and public sector.

There is a limited number of jurisdictions that specifically recognise a constitutional right to privacy, for instance, the Constitution of Brazil, South Africa and South Korea ${ }^{87}$ Besides, where there is no specific provision of the right to privacy in the Constitution, the courts of many jurisdictions have recognised such right implicitly such as Malaysia and India.

The analysis of different provisions of the Constitution of Bangladesh together with related case laws from different common law jurisdictions especially India and Malaysia suggest that the right to privacy is implicit under the right to life and liberty. The absence of specific provisions does not necessarily mean there is no recognition of privacy under the Constitution. The notion of privacy is intrinsically related to the concept of life and liberty in the sense that both concepts basically share the same philosophy. The right to privacy is encompassed by the right to liberty which denotes a right not to interfere with an individual's personal information and dignity.

87 Article 5(X) of Brazil, Article 14 of South Africa, Article 17 and 18 of the South Korea of the respective Constitution. 
The Constitution of Bangladesh does not explicitly recognise the right to privacy, but it did recognise the right to life, personal liberty, dignity and equality of human beings. These rights are not separable or alienable. People inherit these rights by birth. However, it is admitted that the right to privacy is not to be treated as an absolute one.

Although it can be said that the right to privacy may be protected under the penumbra of Article 31, 32 and 43, the scope of Article 32 is wider and offers flexibility to accommodate the right to privacy. The judiciary of Bangladesh can play a pivotal role in establishing and protecting the right to privacy of the citizens. Constitutional protection is paramount in order to check the government arbitrariness. One of the primary concerns for constitutional protection is that an individual cannot bring an action against another individual or even the state under the Constitution in the event of any violation. It is argued that they may do so as the Constitution does indeed provide such a protection. What is needed now is the bravery of the judiciary to clearly define it by encompassing cases relating to protection of personal information in the digital economy. 